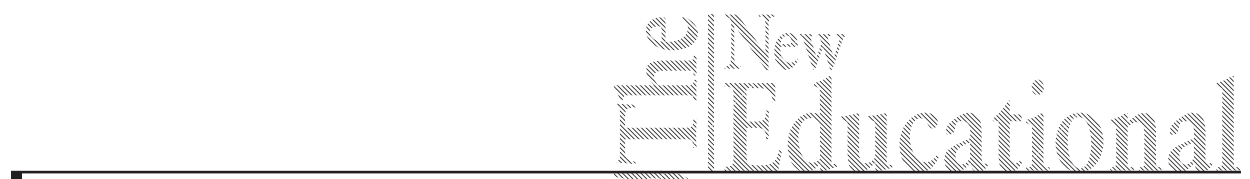

Anikó Fehérvári, Tamás Híves

Hungary

\title{
Trajectories in Hungarian Education - Transition to Secondary School
}

DOI: 10.15804/tner.2017.48.2.12

\begin{abstract}
Hungarian educational policy took a sharp turn in 2010, after the change of regime. The study analyses how pupil/parent preferences and enrolment chances have changed since 2000 in secondary education. The core of the study are KIFIR databases. Their task is to conduct secondary admission processes and to register applications. We have also used the data of the national competence survey to investigate the relationships between social background and student performance.

While the strong government policy prefers vocational training, students and parents tend to turn away from it. However, the chances to enter secondary school have decreased, thus reducing the chances to enter higher education.
\end{abstract}

Keywords: secondary school, tracking, private school, equity

\section{Introduction}

Hungarian educational policy took a sharp turn in 2010, after the change of regime. Act CXC of 2011 on National Public Education and Act CCIV of 2011 on National Higher Education introduced basic changes to education. The content of the training was reviewed, a new core curriculum (NCC) and framework curricula were developed, and are taught from new textbooks. The open competition-based textbook market ceased to exist and was monopolised by a single state publisher 
with a single textbook series. A decentralised governing system was replaced by a centralised one in 2013, and along with it, the previously normative financing was substituted by input financing system. Teacher training was significantly transformed, a previously undivided one-tier model was replaced by a divided one, and a career model was introduced, which envisages a unified career path for all educators, starting from the entrant level. Not only was the lower age limit for entering public education reduced (kindergarten is obligatory from the age of 3 ), but the upper age limit, i.e., the compulsory school age was also changed from 18 to 16 . Breaking the educational expansion is also signalled by other measures, so the time of secondary education expanding upward was curtailed, and institutional state frame numbers were introduced according to education areas (per majors) in higher education, which of course does not preclude higher education institutions from admitting more students, but higher education institutions can only be managed on a fee-paying basis. Out of all the changes we consider it important to emphasise the one in vocational education (still underway). The first significant step of this change was reducing the vocational education from $2+2$ or 3 years to 3 years only in 2013, due to which the content of the education changed, too: the time spent on subjects of general knowledge decreased. The main argument of the economic lobby for changing the system of vocational education was that in this way it could accommodate labour market demands better and produce skilled workers in much larger numbers compared to previous years.

The study analyses how pupil/parent preferences and enrolment chances change in secondary education and to what extent the education policy efforts aiming at reducing expansion and increasing fairness have been enforced. The period of time since the changes were introduced is obviously too short, so we may only talk about short-term tendencies, and they clearly show what unintended consequences were induced by the changes.

The core of the study are KIFIR databases, the Information System on Secondary School Entrance Exams. The KIFIR information system has been in place since 2000 in Hungary, its task is conducting secondary admissions processes and registering applications. We also used the data of the national competence survey to investigate the relationships between social background and student performance, as well as to illustrate the social composition of pupils in certain education categories. 


\section{Demographic characteristics, chances of enrolment}

The Hungarian public education should prepare for a long-term downward trend in demographics, in which the newly-born generations are decreasing in number. Data show (Figure 1) the size of the 15-19 generation and the number of participants in secondary education. We can establish that the number of participants in secondary education was sharply increasing following the change of regime, but after 2011 this tendency stopped and the participation of the 15-19 generation declined. This is probably due to lowering the compulsory school age from 18 to 16 in 2011, as well as due to the structural transformation of secondary school system and to the fact that the upward expansion of education (mainly related to vocational education) stopped.

In international comparison (Table 1), based on OECD EAG trend data between 1995-2010, the Hungarian participation ratios are higher than those of OECD countries or the average of European Union countries (EU21) (OECD, 2015), but as an impact of processes following 2011, this advantage has disappeared and Hungary also shows the EU average value.

Figure 1. Size of the generation of 15-19-year-olds and the proportion of secondary school pupils over the period of 1960-2015

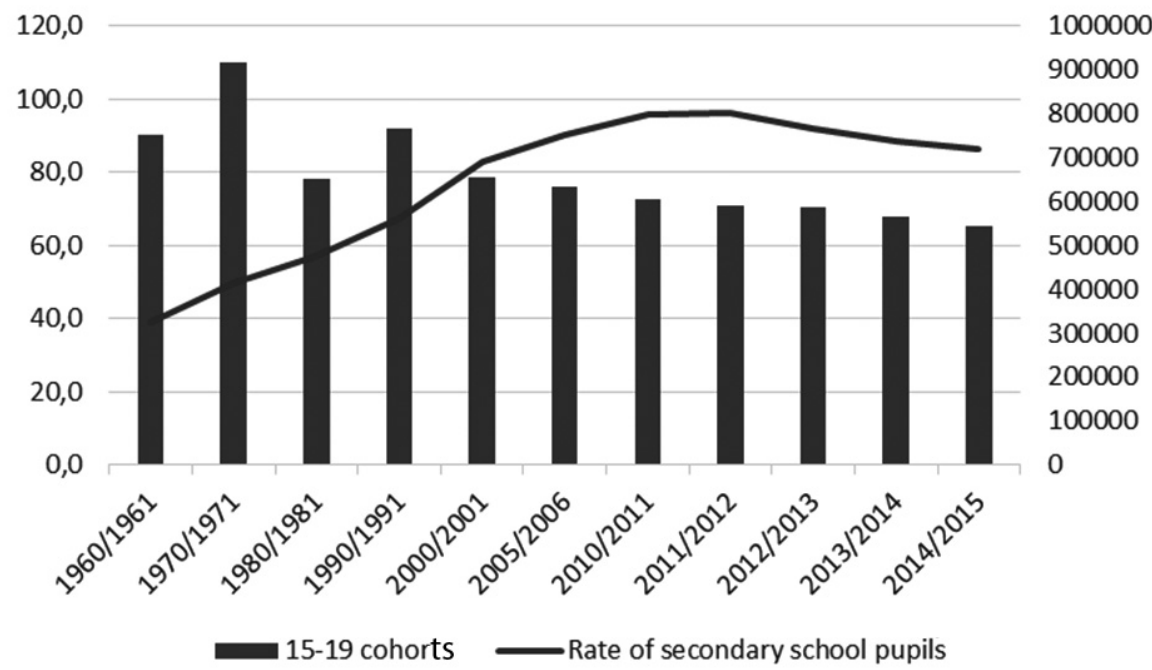

Source: Hungarian Central Statistical Office 
This high participation value is also characteristic of the other countries in the region, in Poland and the Czech Republic 90\% of the 15-19 generation takes part in education, and the ratio remained this high in these two countries.

Table 1. Trends in enrolment rates of 15-19 (1995-2013)

\begin{tabular}{lccccc}
\hline \multicolumn{1}{c}{ Countries } & $\mathbf{1 9 9 5}$ & $\mathbf{2 0 0 0}$ & $\mathbf{2 0 0 5}$ & $\mathbf{2 0 1 0}$ & $\mathbf{2 0 1 3}$ \\
\hline Hungary & 64 & 78 & 87 & 92 & 87 \\
\hline Poland & 78 & 84 & 92 & 93 & 90 \\
\hline Czech Republic & 66 & 81 & 90 & 90 & 90 \\
\hline EU21 & 78 & 81 & 86 & 87 & 87 \\
\hline OECD & 73 & 77 & 81 & 83 & 84 \\
\hline
\end{tabular}

Source: OECD EAG, 2010, 2015, C1 indicator

\section{Secondary enrolment trends}

The Hungarian school system kept the Soviet type primary school education even after 1990, i.e., primary school comprises 8 grades. Educational policy gave way to 6 and 8 grade high schools after 1985, which meant that the unified primary education is broken already after the $4^{\text {th }}$ grade. Pupils can choose between three types of education following primary school: secondary school, secondary vocational and vocational school. The former two end with a school leaving exam, which is the admission condition for higher education, vocational schools basically end with entering the labour market.

When applying for a secondary school pupils are allowed to mark as many schools as they want ${ }^{1}$, the preference of the pupil or parent is indicated by indicating that institution as primary preference. Figure 2 illustrates the changes in the applications for the primary preference and also the differences between the different education types. The timeline figure shows how the proportion of pupils applying for different education types has changed. In the past decade and a half, the number of applicants for secondary school has continuously increased, in 2001 only $30 \%$ and in 2015 already $46 \%$ of applicants marked a secondary school as their school of choice. This huge rise - more than $50 \%$ increase in 15 years - indicates that pupils and their parents consider secondary education to be primarily

1 There are numerous specialisations within the three main education types, so the typically 4-year long education may become 5 years long. 
and increasingly successful and more important from the point of view of higher education. The background of this phenomenon is that the majority of secondary school graduates want to study in higher education institutions. Although both those who graduated from secondary vocational schools and secondary schools have the opportunity to continue their education (since both school types end with a school leaving exam), still, pupils from secondary schools are more likely to be able to plan their higher education, since the gap between opportunities has grown wider compared to 2000 , what is more, secondary vocational schools show a rising opportunity of self-selection, i.e. fewer pupils apply for higher education institutions (Szemerszki, 2014).

Figure 2. Places of primary preference, according to the type of education (\%)

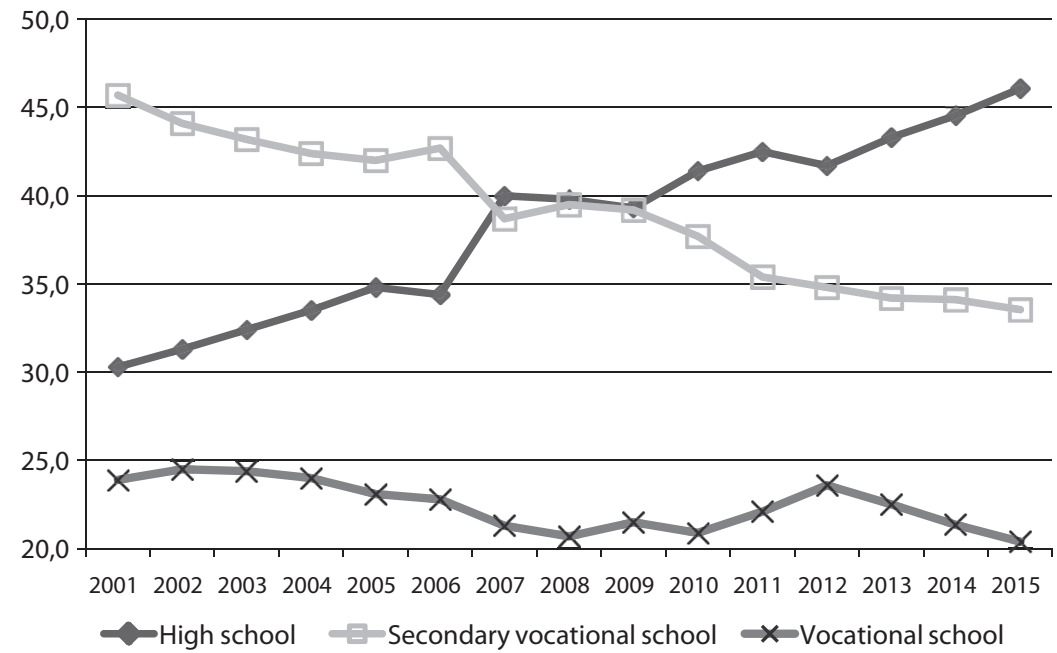

Source: KIFIR

Based on primary preferences, the number of pupils applying for a secondary school has increased and, simultaneously, the number of pupils applying for a secondary vocational school has decreased. Timeline data illustrates that 2007 was a turning point when a significant break in applications for both types of school appeared, namely, there was a huge increase in applications for secondary schools and a significant decrease in the applications for secondary vocational schools. This was the first year when there were more pupils who wanted to enter a secondary school than a secondary vocational school. At the end of the century, secondary vocational school was in the lead by $15.4 \%$ compared to secondary 
school, but this advantage declined, and by 2015 secondary school is in the lead by $12.5 \%$.

The further studying ratio of secondary vocational schools changed more slowly and with certain fluctuations it showed a decreasing tendency. The number of applicants started to increase again in 2010, but the process stopped in 2013, and in the last 3 years there has been a strong decline, despite the continuous efforts of the government and the educational policy.

Vocational education is unpopular among parents and pupils for several reasons. First of all, there is no easy path from there to higher education, although there are some correctional learning ways, nevertheless, if we look at the reinforcement of chances for further education, we can see increasingly worse prospects (Mártonfi 2013). Apart from the above, vocational education is less favourable than the other two education types (secondary school and secondary vocational school) both from the employability and income points of view (Hajdú et al., 2015).

\section{State and private education}

It can be seen, therefore, that vocational education has the highest chances of admission, as compared to lower chances of admission into secondary school. Figure 4 illustrates greater changes, which happened between 2009-2010 and 2013-2015. Let us consider the past two years, examining the data according to school types, specialisations and maintainers in more detail. Figures 3 and 4 show courses offered in 2013 and 2015 according to school maintainers. Both in vocational education and general education, looking at the internal proportions, the number of state schools' specialisations decreased. Within vocational education, this decline is $2-3 \%$ and the transformation benefitted religious schools. Within general education, the greatest decline appeared in the number of secondary school seats with 4.5 grades in the two-year interval (4.2\%), and here too it was the religious schools that benefitted from the transformation. The number of pupils attending private secondary schools also rose, primarily in secondary schools with 8 grades.

Both religious and private institutions have increased their active role in secondary education, but it may also be concluded that schools maintained by church gained ground within secondary school education. Although within the examined two-year period the composition of the maintainer of institutions offering 8-grade high school education has not changed significantly, by 2015 this was the only type of education where the ratio of state and private institutions was of similar extent. 
Figure 3. Announced places according to the type of vocation and the maintainer, 2013-2015

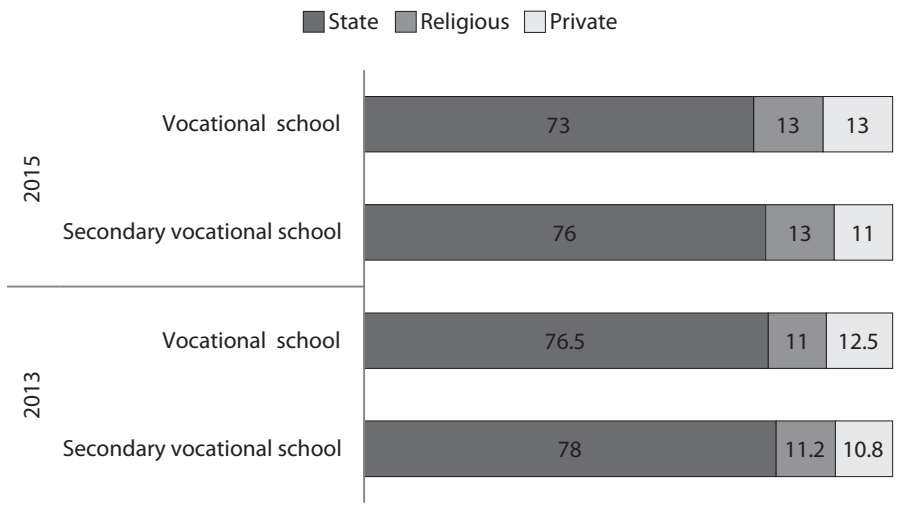

Source: KIFIR

Figure 4. Announced places according to the type of general education and the maintainer, 2013-2015

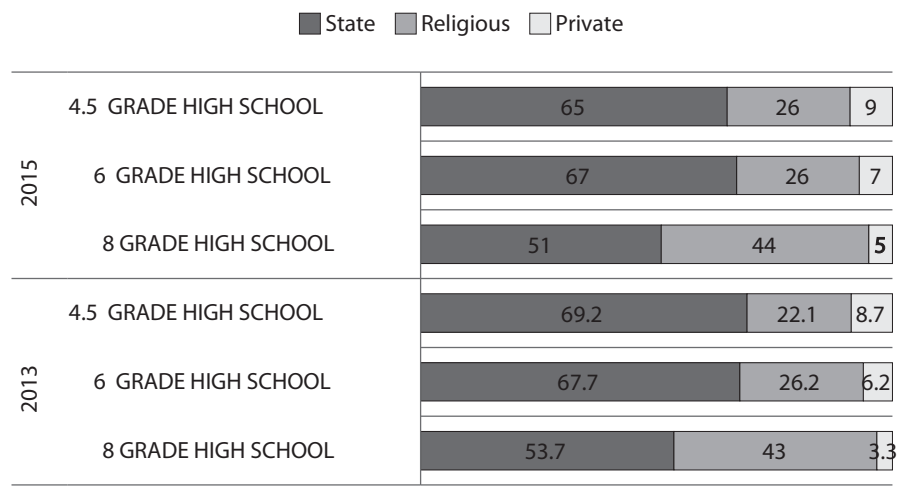

Source: KIFIR

\section{Social inequalities in secondary education}

Pupils of different social background study in different education programmes. Hungarian elite enrol their children in 6- and 8-grade secondary schools, in which there are almost no multiple disadvantaged students. Approximately every tenth secondary school pupil, every third secondary vocational school students 
and every second vocational school pupil is a multiple disadvantaged student. Hungarian secondary education is segmented and highly hierarchic.

PISA measurement data show that the differences in student performance are extreme among Hungarian schools, and that the explanatory role of the socioeconomic status within the performance is higher, there has been no important change since the onset of the measurements. The results of the domestic national competence measurement also shed light on the fact that this explanatory power has increased over the years, i.e., the more time a pupil spends in school, the larger the impact of their family background on their school performance is. All this indicates that the Hungarian school system converts the differences in social background into differences in performance and therefore creates a type of education for each group.

Tables 2 and 3 illustrate the differences between the education types according to social composition and abilities. It can easily be spotted that the pupils with the best performance attend schools in which more than half of the pupils belongs to the highest quintiles according to their social background. At the same time, almost two thirds of the pupils from vocational schools at the lowest rank belong to the lowest quintiles. According to the social composition, middle class is represented by secondary vocational school, which also refers to student performance, which equals the national average. It may also be seen, however, that this middle class was heading downwards already in 2008, since there were $6 \%$ more students belonging to the lowest quintiles than to the highest one. Taking into consideration the data from 2015, the downward slide is fairly obvious. Comparison of the data from the period of 2008-2015 calls attention to another process, which was not signalled by multiple disadvantage background data. Although in 2008 there were still students belonging to the lowest quintiles in 6- and 8-grade schools, they vanished, they had been completely ousted from them by 2015 .

Table 2. The type of school and pupil composition based on pupil composition in districts nationwide, $\%$

\begin{tabular}{lccccc}
\hline $\begin{array}{c}\text { type of edu- } \\
\text { cation }\end{array}$ & 1. district & 2. district & 3. district & 4. district & $\begin{array}{c}\text { average competence } \\
\text { point, mathematics }\end{array}$ \\
\hline $\begin{array}{l}\text { 8-grade high } \\
\text { school }\end{array}$ & 4 & 12 & 30 & 55 & 1838 \\
\hline $\begin{array}{l}\text { 6-grade high } \\
\text { school }\end{array}$ & 8 & 15 & 21 & 56 & 1810 \\
\hline $\begin{array}{l}4 \text {-grade high } \\
\text { school }\end{array}$ & 7 & 17 & 27 & 49 & 1704 \\
\hline
\end{tabular}




\begin{tabular}{lccccc}
\hline $\begin{array}{l}\text { type of edu- } \\
\text { cation }\end{array}$ & 1. district & 2. district & 3. district & 4. district & $\begin{array}{c}\text { average competence } \\
\text { point, mathematics }\end{array}$ \\
\hline $\begin{array}{l}\text { secondary } \\
\text { school }\end{array}$ & 18 & 35 & 35 & 12 & 1616 \\
\hline $\begin{array}{l}\text { vocational } \\
\text { school }\end{array}$ & 65 & 25 & 9 & 1 & 1454 \\
\hline nationwide & 25 & 25 & 25 & 25 & 1629 \\
\hline
\end{tabular}

Contingency Coefficient 0.563, chi2: 000

ETA,781 sig: .000

Source: OKM, 2008 10-grade site data

Table 3. The type of school and pupil composition based on pupil composition in districts nationwide, \%

\begin{tabular}{lccccc}
\hline type of education & 1. district & 2. district & 3. district & 4. district & $\begin{array}{c}\text { average } \\
\text { competence point, } \\
\text { mathematics }\end{array}$ \\
\hline $\begin{array}{l}\text { 8-grade high } \\
\text { school }\end{array}$ & 0 & 8 & 25 & 67 & 1817 \\
\hline $\begin{array}{l}\text { 6-grade high } \\
\text { school }\end{array}$ & 1 & 11 & 24 & 64 & 1798 \\
\hline $\begin{array}{l}\text { 4-grade high } \\
\text { school }\end{array}$ & 6 & 15 & 28 & 50 & 1700 \\
\hline secondary school & 20 & 36 & 35 & 9 & 1602 \\
\hline vocational school & 63 & 28 & 9 & 0 & 1432 \\
\hline nationwide & 25 & 25 & 25 & 25 & 1614 \\
\hline
\end{tabular}

Contingency Coefficient 0.595, chi2: 000

ETA,781 sig: .000

Source: OKM, 2015 10-grade site data

We have already mentioned PISA measurements, which show the characteristics of the Hungarian public education. In what follows we will present three studies which aim at placing Hungarian secondary education in the Central and Eastern European context.

The segregation index shows polarisation according to social background. An English research group (Jenkins, Micklewright and Schnepf, 2008) calculated the extent of segregation regarding 27 countries, using PISA data (from 2000 and 2003) and applying and comparing a two-way segregation index. They were primarily interested in English secondary school, but Hungary was also present among the 27 countries. One of the applied indexes is related to Duncan and 
Duncan (1955) and the other one to Hutchens $(2001,2004)$. Both indexes are in the domain between 0 and 1 , one is absolute and the other calculates proportional differences. While in the order of countries closer to 0 there were some differences between the two indexes (Scotland, Japan, Sweden), there was no such difference with regards to the most segregated secondary schools. Based on both indexes, Hungary has the most segregated secondary school system. Besides the Hungarian one, the secondary school systems in Belgium and Germany are also strongly segregated. Jenkins et al. also studied the degree to which the private sector increases segregation in education in England. Their conclusion was that private education applied segregation to a lesser extent, but the biggest problem is still that of pupils being distributed unevenly in the public sector, according to their social background.

In Hungary, segregation in secondary schools dates back to distant past, as secondary education was already divided between the two world wars, and this could not be changed either by socialism or the change of regime. What is more, the change of regime brought about the first 6- and 8-grade secondary schools, which further diverged the Hungarian education system and grounded the state possibility for elite education. There are examples for elite education within the state sector beyond the borders of Hungary. Mateju and Strakov (2005) shed light on a new type of school (multi-year middle schools) within the lower level secondary education in the Czech Republic at the time of the change of regime, which also serves the purpose of educating the local elite. Mateju and Strakov used PISA data (SES index) to illustrate that according to their socioeconomic status $70 \%$ of children attending multi-year middle schools belong to the upper two quintiles, while only $15 \%$ of the children belong to the lower two quintiles. In the case of a more even distribution, this proportion would be $40-40 \%$, as it is in the case of the other type of school (basic school) $-42 \%$ and $37 \%$ is the distribution in upper and lower quintiles, respectively. (The data of the basic school also indicate that Czech education is not as segregated as Hungarian education). The family background differences between the two types of schools can also be seen in the reading comprehension results and further education data, since the pupils from the multi-year middle schools achieve better test results and a larger proportion of them has plans for further education. Namely, while $57 \%$ of the basic school pupils from the lower two quintiles according to their social status plan further education, this ratio among the pupils from the upper two quintiles is $82 \%$ and among the multi-year middle school pupils it is $88-96 \%$. The Czech study, therefore, shows that the choice of secondary school basically determines entering higher education. The Polish study reached the same conclusion. Domański 
(2006) studied the relationship between family background and higher education in the period of 1982-2002. The conclusion was that previous education and the choice of secondary school strongly influence higher education studies. The Polish education reform, which started in 1999, however, did transform the post-socialist school system which was also present in Hungary. The most significant structural reform was decreasing the length of primary school education and deleting the possibility of early vocational education. This does not, of course, mean that higher education admission chances do not still depend on the choice of secondary school, since the higher secondary school system still retained the threefold division into general school (liceum), vocational and secondary vocational school (technikum), but the increase in general education contributed to increased basic competences, especially among the lowest social groups, i.e., the biggest winners of the Polish reform are pupils in vocational schools (Jakubowski, 2015). The piece of study analysing the impact of the Polish reform also reflects the education policy of the Visegrad Four. It establishes that all the four (i.e., at that time three) countries had a similar starting point in 1990 and introduced numerous reforms in their education systems, but the Polish reform had two elements which the other three countries did not touch upon. These were: duration of compulsory education, comprehensive education, implementation of monitoring methods, and monitoring student achievement.

The inequalities interpret the individual's later career, their job and income. We can see two large groups of education systems: in one of them vocational education is a part of public schooling (apprenticeship), while in the other one the emphasis is on general education. The German, Austrian and Danish school systems belong to the former type, and Anglo-Saxon countries represent the latter type. There was a study which, based on the research on adults' reading comprehension, analysed which system seems more favourable for the individual's later career. Hanusek et al. $^{2}$ (2015) examined the IALS data of 11 countries in the period of 1994-1998, separating the databases of German and Austrian micro-censuses, analysing the data of countries where the traditional apprenticeships are available. They reached the conclusion that those who complete a secondary vocational school or an apprenticeship have a shorter path to the labour market, i.e., the transition from education to a job is easier, yet they may find themselves in a disadvantageous position later in life, may be affected by unemployment to a greater extent than those who graduate from a general school. One explanation the researchers

2 http://hanushek.stanford.edu/sites/default/files/publications/hswz\%20vocatlk;;ional\%20 final.pdf 
gave for this is that graduates from secondary vocational schools are less able to assimilate to the technological and structural changes of the economy. Besides the disappearance of the employment advantage, there is also the negative effect on the income, compared to those who graduated from general education.

\section{Conclusion}

The study analyses the Hungarian trends of secondary education based on the timeline data of institutional databases of Information System on Secondary School Entrance Exams.

Hungary is among the countries in which a large proportion of an age group participated in vocational training or apprenticeship during the period of socialism, and after the transition parents turned to general education. Traditional apprenticeship has also changed, because two years of general education were introduced preceding professional training and general education in vocational training has also increased. There was a great change of direction in education policy after 2010, as a result of which the two-year long training after primary school was abolished, and the content of general education within vocational training was decreased. In addition, there is a strong government intention to increase secondary enrolment in apprenticeships and vocational schools. It is visible, however, that religious and private sectors offer an alternative to meet the consumer demand. There are, unfortunately, also losers in this process, the emerging social groups of lower status, who for the past decade have had better access to general education, elite education, but have recently been completely excluded from it.

\section{References}

Domański, Henryk. 2006. Barriers of the Selection to Secondary and University-Level Education. Polish Sociological Review 156 (4): 471-487.

Duncan, Otis Dudley, and Beverly Duncan. 1955. A methodological analysis of segregation indexes. American Sociological Review 20 (2): 210-217.

Hajdú, T., Hermann Z., Horn D., Kertesi G., Kézdi G., Köllő J. and Varga, J. 2015. Az érettségi védelmében [In defence of secondary school leaving exam.] BWP - No. 1.

Hutchens, Robert 2001. Numerical measures of segregation: desirable properties and their implications. Mathematical Social Sciences 42 (10): 13-29.

Hutchens, Robert 2004. One measure of segregation. International Economic Review 45 (2): 555-578. 
Jakubowski, Maciej. 2015. Opening up opportunities: education reforms in Poland. IBS Policy Paper: 1

Jenkins, Stephen P., John Micklewright, and Sylke V Schnepf. 2008. Social Segregation in Secondary Schools: How Does England Compare with Other Countries? Oxford Review of Education 34 (1) 21-37.

Mártonfi, György. 2013. Korai iskolaelhagyás a magyarországi szakképzésben [Early school leaving in Hungarian vocational education.] CEDEFOP REFERNET Hungary

Mateju, Petr and Jana Strakov. 2005. The Role of the Family and the School in the Reproduction of Educational Inequalities in the Post-Communist Czech Republic. British Journal of Sociology of Education 26 (1) 17-40.

OECD 2015. Education at a Glance 2014. Paris: OECD Publisher

Szemerszki, Marianna. 2014. A középiskolából a felsőoktatásba - jelentkezési és felvételi tendenciák [From secondary school to higher education - application and entrance exam tendencies.] Felsőoktatási Mühely (1): 47-63. 